\title{
Instruction of English for Academic Purposes for Freshman Non-English Majors: Perspective and Practice
}

\author{
Dahu Zheng \\ College of Foreign Languages, University of Shanghai for Science and Technology, Shanghai, China \\ Email: greatlakedh@126.com
}

How to cite this paper: Zheng, D. H. (2022). Instruction of English for Academic Purposes for Freshman Non-English Majors: Perspective and Practice. Creative Education, 13, 627-636.

https://doi.org/10.4236/ce.2022.132039

Received: January 18, 2022

Accepted: February 19, 2022

Published: February 22, 2022

Copyright ( 2022 by author(s) and Scientific Research Publishing Inc. This work is licensed under the Creative Commons Attribution International License (CC BY 4.0).

http://creativecommons.org/licenses/by/4.0/ (c) (i) Open Access

\begin{abstract}
An increasing number of universities in China have offered EAP (English for Academic Purposes) to university students. However, issues as to what and how to teach academic English to freshman non-English majors remain unaddressed. This paper, adopted secondary research method, is intended to explore the deficiency Chinese college students may have in participating in communication in the academic community. The result shows that inability to think critically, lack of genre awareness, deficiency in understanding features of academic discourse and the linguistic features of English scientific and technical papers, improper literature citation and inaccurate expression of stance are a major threat to academic progress and success. The paper suggests that six aspects of academic awareness should be raised, and academic skills related be developed when EAP program is offered to freshman non-English majors, in hope of providing insights for the effective implementation of academic English teaching in China.
\end{abstract}

\section{Keywords}

EAP Teaching, Secondary Research, Academic Awareness, Freshman Non-English Majors

\section{Introduction}

English for Academic Purposes (EAP) is a variant of English used by academic researchers for knowledge construction, information exchange and academic communication to advance their disciplines (Wei, 2016). In terms of content, it can be categorized into English for General Academic Purposes (EGAP) and English for Specific Academic Purposes (ESAP) (Dudley-Evans \& St John, 1998). 
Originating in the UK in the 1960s (Jordan, 1998), EAP instruction was designed to help international students in UK universities adapt to English-mediated learning and research, as a way of facilitating acquisition of academic language knowledge and of skills of professional learning and research (Hyland \& Hamp-Lyons, 2002). Thus, EAP has two main attributes: needs-driven and research-informed (de Chazal, 2014).

As the overall English proficiency of non-English majors in Chinese universities keeps improving, there is some consensus among teachers about the necessity of teaching academic English to them. The College English Teaching Guidelines (2020) consolidates the position of academic English teaching as an integral part of university English teaching in the hope that students who have a good command of general English will be able to "write academic papers in the correct style and participate in international academic communication in English in the future" (Yang, 2018: p. 33). Many universities have started to offer a series of academic English courses. However, given that EAP courses are now offered to the freshman non-English majors in China, two aspects are noteworthy. On the learners' part, they have not felt the academic pressure of learning and research in English, while on the teachers' part, such core issues as what to teach and how to teach have not been addressed systematically, which has directly led to the phenomenon that the current academic English teaching in China is generally "different" in terms of teaching objectives, methods, course focus, and curricu$\operatorname{lum}(\mathrm{Yu}, 2014)$.

There are three major schools of EAP teaching: study-skills-based EAP, disciplinary-texts-based EAP, and literacy-practice-based EAP, each of which is adopted as either collaborative teaching model between language experts and disciplinary teachers (Mandell et al., 2015) or team teaching model (Li et al., 2019), in which language teachers help students master the chapter structure and language features of subject papers, and teachers of different disciplines teach how to present data, and the strategies for publishing papers (Cargill et al., 2017). In China, EAP courses are carried out by English teachers who had basic knowledge of ESP genre pedagogy, employing various foreign teaching models such as genre pedagogy, data-driven learning, research writing groups, for the purpose of helping postgraduate publish research papers in English (Lei \& Li, 2019). However, these content-based pedagogies, in which teachers need to have a deep disciplinary background (de Chazal, 2014), aimed to establish an explicit connection between language skills and disciplinary content, are not very effective, because students still cannot write academic papers in English in the correct style (Zhang, 2010; Luo, 2001). In recent years, there have been voices calling for colleges to start academic English teaching from the junior undergraduate level to meet the students' future needs (Cai, 2019).

Many universities have tried to carry out school-based academic English teaching (Gong, 2018). Cai (2016) suggests that academic English teaching should cultivate students with competence of "general academic English skills + professional language knowledge + interdisciplinary scientific literacy", which has 
been hailed as representing the core idea of Chinese EAP epistemology (Gong, 2018). However, the teaching requirement only remains at the macro level without in-depth study on specific teaching contents.

In this situation, researchers suggest that teachers "raise students' awareness, give them a variety of experiences and exposures, encourage their analyses and critique of texts and contexts" Johns \& Swales (2002: p. 26), while developing students' academic thinking and academic skills (Lv et al., 2016), and ultimately familiarizing students with and learning to use the characteristic norms of reference in international academic discourse communities (Wei, 2016). However, few studies have systematically and comprehensively elucidated what academic awareness and related skills should be developed by the freshman non-English majors in learning EAP. Combined with the author's teaching practice, this paper, through secondary research, is intended to explore the issues as to what awareness to be raised and how to develop the related skills by the freshman non-English majors, in the hope of providing insights for the effective implementation of academic English teaching in China.

\section{Methodology}

Academic awareness is referred to as the ability to understand a variety of issues systematically, comprehensively and professionally, and to use scientific, objective and reasonable methods to present researchers' point of view. Academic English skills are the ability to use various linguistic means to achieve decent and effective academic communication, such as writing persuasive academic papers and presenting academic views appropriately (Ma et al., 2013). This paper, combined with the author's teaching practice, employs secondary research method surveying literature published in the key journals in the past two decades, to find out the deficiencies college students may have in participating in communication in the academic community, thus preparing freshman non-English majors for their professional learning and research in the future.

\section{Findings}

\subsection{Results of the Survey of Related Literature}

Literature available finds what follows is the major obstacles to Chinese college students academic progress and success.

1) inability to think critically

Academic English proficiency is closely correlated with scientific research (Liu \& Liu, 2020). Scientific research is a complex, problem-solving activity, and asking questions and identifying problems are in turn the key to scientific research activities. Questions-raising is a good start for research, determines the choice of research methods, and ultimately has a significant impact on the quality of research (Mackey \& Gass, 2015). Research questions are established based on researcher's interest, on relevant literature on the issue of interest; and researchers can only explore the research gap in current research by reading existing rele- 
vant literature critically, and then propose ideas and confirm them, with the ultimate goal of proving the value and necessity of the new research (Kwan, 2006).

However, due to the test-oriented teaching at the primary to secondary school level in China, students' main task centers on adsorbing knowledge, thus resulting in a deficiency of the spirit of questioning and challenging, as well as inability to analyze problems in depth (Atkinson, 1997; Kim, 2006; Floyd, 2011). Academic English teaching, therefore, should cultivate students' critical thinking, help students learn how to summarize, evaluate related researchers' views, and elaborate their own views.

\section{2) lack of genre awareness}

A genre is a purposeful, socially governed communicative event, which a particular discourse community considers to belong to the same category (Swales, 1990; Bhatia, 1993), with characteristics such as statute, decency, recognizability, and diversity. Generic competence is the ability to select the appropriate discourse category to "do something" in an agreed social context and in the practice of culturally relevant discourse in a specific professional discipline, which can distinguish between "insiders" and “outsiders" (Bhatia, 2004). However Dudley-Evans (1999) finds that even the doctoral dissertation remains a "neglected" genre.

To master a genre, learners must accept the genre and the statutes and values of the discourse community (Devitt, 2009). Hyland (2005) argues that genre has become a powerful tool for non-native speakers to understand the features of academic discourse, so EPA teaching should incorporate genre awareness cultivation throughout the process of teaching academic English writing (Lei \& $\mathrm{Li}$, 2019).

3) ignorance of the linguistic features of English scientific and technical papers

An underlying academic language culture is accepted by all scientific community members. In terms of academic discourse, there exist typical linguistic features. For example, in terms of syntax, the simplicity of academic discourse often conveys high-density information in a limited space through complex syntactic structures such as noun structures, subordinate clauses, and embedded clauses (Biber et al., 2011). In other words, precise and concise wording and complex and compact sentences are required in academic English writing. In terms of vocabulary, there are technical vocabulary, interdisciplinary general academic vocabulary, and functional vocabulary (Crosson \& Lesaux, 2013; Coxhead, 2016).

However, one study of $\mathrm{PhD}$ theses ( $\mathrm{Yu}, 2014$ ) found that ignorance of the linguistic features of English scientific and technical papers poses a major obstacle to writing academic papers in the correct style by $\mathrm{PhD}$ graduates. Academic English proficiency cannot be automatically transformed from general English proficiency, therefore, much importance should be attached to teaching academic language features in the EAP instruction. Through training and internalization, students can gradually migrate from general English proficiency to academic English proficiency, thus helping learners acquire communicative 
competence for specific academic and cultural contexts (Hyland \& Hamp-Lyons, 2002).

\section{4) improper citation of literature}

Academic ethics is defined as the ethical norms and guidelines that academic groups or individuals should follow when they are engaged in academic activities, and it greatly affects the quality of research paper, which determines whether students will be able to write research articles that meet the norms and are approved by their instructors or accepted by academic journals (Lv et al., 2016). Studies have shown that Chinese students know little of how to cite literature properly to avoid plagiarism (Zou, 2015). Therefore, EAP teaching should focus on cultivating students' compliance with academic ethics.

\section{5) inaccurate expression of stance}

The construction of academic perspectives requires not only the objective presentation of research data, but also the reasonable expression of the researcher's position and the manifestation of authorship in order to have a say in the academic field (Hyland, 2005; Lancaster, 2016; Jiang \& Ma, 2019). Reasonably expressing the author's position and conforming it to the statutes of the academic community is not easy for academic novices of second language learners. Studies have found that academic novices are unable to accurately use position resource words to express rhetorical persuasion in the results and discussion sections of their papers (Mansourzadeh \& Ahmad, 2011). Therefore, stance expressions should be another focus of the teaching academic English (Hyland, 2018; Wang \& Liu, 2013; Xu, 2015).

To conclude from available evidence, much has to be done to help students participate in international academic communication in English.

\subsection{Approaches to Academic Awareness-Raising and Skill Development}

Project-based Learning (PBL) and text analysis methods, advocated by academic English teaching practitioners have been adopted in EAP teaching (Cai, 2019). PBL is a teaching method that emphasizes student-led inquiry, in which students, under the guidance of the teacher, select a research project or topic and actively collect information, analyze information, acquire knowledge, apply knowledge, and solve problems through research. This teaching method can effectively configure the three elements of EAP course: skills-based, text-based and practice-based (Hyland, 2006), and help students acquire and use language through project-based research (Alan \& Stoller, 2005). The teaching content of academic English covers language skills ranging from general academic vocabulary, normalization structures, complex syntactic structures such as subordinate clauses and embedded clauses, and the reasons for and use of "hedging", to literature reading skills, note-taking methods, and such skills as quoting, paraphrasing, summarizing, and synthesizing that need to be mastered to avoid academic plagiarism, to topic selection, topic formulation, abstract, introduction, definition, data presentation. 
The course is arranged as follows: Learners are first introduced to the differences between general English and academic English by providing them with two versions of simple text in general English and academic English helping them perceive the difference between the two in order to arouse their interest in academic English learning, followed by explaining the features of academic language. Then, five research papers commonly accepted by students of different disciplines are selected for interpretation to encourage students to understand the features of academic discourse. Then the principles of deciding research topic, basic academic English skills and norms are discussed in terms of why to do, how to do and what to do that way, for example, why citation is used, how to effectively draw from sources, what language signals a citation.

In the third week, after the principles of deciding research topic are introduced, each student is required to find a topic (or idea) from their daily life or a topic of their own interest according to the principles, getting ready for a presentation based on the format of "5-Minute Research English Speech Contest for Chinese Students". From the $5^{\text {th }}$ week onwards, three students from different groups are given a 3 - 5 minute oral presentation on their chosen topic or idea with the help of PPT, one of whom represents his or her group to present their chosen topic for the first time. In $8^{\text {th }}$ week, three students will continue to report on their chosen topic in each period, two of whom report for the second time on behalf of their group on their revised topic, with peer questions and teacher comments made again. In $13^{\text {th }}$ week, each group submits the first draft of their research report, and the teacher makes comment on it for the third time. In last week of the semester, the group members report their research results and submit an approximate 1500-word IMRD (Introduction, Methodology, Results, Discussion) research paper with an abstract of about 250 words and References.

This classroom environment helps to establish and strengthen an initial explicit connection between the content and academic awareness and skills related in order to enhance the practical significance and transferability of skills related; meanwhile, it helps familiarize students with the research process and elements of scientific research in their studies.

At the end the semester, six students were randomly invited to participate in an interview. What follows is a selection of some of the most typical student reflections made:

"I do find the difference between general English and Academic English, so I think I do need to learn it." (Jin)

"I feel that I have learned a lot now from this course though I feel puzzled most of the time in class at the beginning of this semester, like IMRC/D." $(\mathrm{Lu})$

"This course is useful for me because I plan to study in English-speaking countries after graduation. From the course I learn what a research paper is like, how to cite others' ideas, to discover the gap of others' research, and how to ask research questions." (Fan) 
"Your comment of our group's project helped me a lot and deepened my knowledge of academic language and thesis structure. At least it helped me know what mistakes that I should not make." (Lin)

"This is the first time I learned that conclusions could only be reached on the basis on data obtained from survey or experiments conducted." (Xu)

"I feel that I can't learn so many things in class because all these are quite new to me, like how to define a concept or term and how to cite, I feel it so complicated that I can't remember so many things. I hope that this course will be put off later, even if it is offered a semester later." (Liu)

As these reflections show, freshman non-English majors know very little about scientific research and research papers writing. They are just like pieces of blank sheet on which EAP teachers may feel free to write. Thus, EAP teachers should have in mind first what and how to teach novice students in the EAP.

Another question worthy of further research in terms of the students' response is when is the best time to offer EAP to college students.

Given that EAP are currently carried out mainly by general English teachers in China, most of whom "do not understand other disciplines or other pedagogical practices well enough to give our students templates for success" (Johns \& Swales, 2002: p. 26); the students are not learners in the context of the subject matter either (de Chazal, 2014), for whom writing academic papers is like playing a game whose rules are not yet known (Read et al., 2001). The author suggests that when teaching academic English to novice students, teachers should focus on developing students' six aspects of awareness including awareness of scientific research, academic genre awareness, awareness of academic language, awareness of academic ethical norms, evidence-based awareness, awareness of academic identity construction, and skills related to academic activities.

\section{Conclusion}

This paper, based on available literature and practices, discusses the course focus of the EAP program to freshman non-English majors by exploring the deficiencies college students have and the six aspects of academic awareness suggested are subject to further validation by empirical studies of journal editors and reviewers in the future.

\section{Conflicts of Interest}

The author declares no conflicts of interest regarding the publication of this paper.

\section{References}

Alan, B., \& Stoller, F. L. (2005). Maximizing the Benefits of Project Work in Foreign Language Classrooms. English Teaching Forum, 43, 10-21.

Atkinson, D. (1997). A Critical Approach to Critical Thinking in TESOL. TESOL Quarterly, 31, 71-94. https://doi.org/10.2307/3587975 
Bhatia, V. K. (1993). Analyzing Genre: Language Use in Professional Settings. London \& New York: Longman.

Bhatia, V. K. (2004). Worlds of Written Discourse. London: Continuum.

Biber, D., Gray, B., \& Poonpon, K. (2011). Should We Use Characteristics of Conversation to Measure Grammatical Complexity in L2 Writing Development? TESOL Quarterly, 45, 5-35.

Cai, J. G. (2016). Theoretical Foundations of EAP as an Independent Course in Chinese Tertiary Education. Technology Enhanced Foreign Language Education, 1, 9-16.

Cai, J. G. (2019). Design of a Project-Based Blended Instructional Model for EAP. Journal of PLA University of Foreign Languages, 3, 39-47.

Cargill, M. et al. (2017). Scientists Publishing Research in English from Indonesia: Analysis Outcomes of a Training Intervention to Inform Institutional Action. In M. Cargill, \& S. Burgess (Eds.), Publishing Research in English as an Additional Language: Practices, Pathways and Potentials. Adelaide: University of Adelaide Press.

https://doi.org/10.20851/english-pathways-08

Coxhead, A. (2016). Reflecting on Coxhead (2000), “A New Academic Word List”. TESOL Quarterly, 50, 181-185. https://doi.org/10.1002/tesq.287

Crosson, A. C., \& Lesaux, N. K. (2013). Connectives: Fitting Another Piece of the Vocabulary Instruction Puzzle. The Reading Teacher, 67, 193-200.

https://doi.org/10.1002/TRTR.1197

de Chazal, E. (2014). English for Academic Purposes. Oxford: Oxford University Press.

Devitt, A. (2009). Teaching Critical Genre Awareness. In C. Bazerman, A. Bonini, \& D. Figueriredo (Eds.), Genre in a Changing World (pp. 337-351). Fort Collins, CO: The WAC Clearinghouse. https://doi.org/10.37514/PER-B.2009.2324.2.17

Dudley-Evans, T. (1999). The Dissertation: A Case of Neglect? In P. Thompson (Ed.), Issues in E AP Writing Research and Instruction (pp. 28-36). Reading University: CALS.

Dudley-Evans, T., \& St John, M. J. (1998). Developments in English for Specific Purposes: A Multi-Disciplinary Approach. Cambridge: Cambridge University Press.

Floyd, C. B. (2011). Critical Thinking in a Second Language. Higher Education Research \& Development, 30, 289-302. https://doi.org/10.1080/07294360.2010.501076

Gong, R. (2018). Conceptual Structures of University EAP Instruction in China and English-Speaking Countries: A Comparative Study. Journal of the Foreign Language World, 1, 62-70.

Hyland, K. (2005). Metadiscourse: Exploring Interaction in Writing. New York: Bloosbury Publishing.

Hyland, K. (2006). English for Academic Purposes: An Advanced Resource Book. London: Routledge.

Hyland, K. (2018). Sympathy for the Devil? A Defense of EAP. Language Teaching, 51, 383-399. https://doi.org/10.1016/S1475-1585(02)00002-4

Hyland, K., \& Hamp-Lyons, L. (2002). EAP: Issues and Directions. Journal of English for Academic Purposes, 1, 1-12. https://doi.org/10.1016/S1475-1585(02)00002-4

Jiang, F., \& Ma, X. (2019). Positioning and Proximity of Reader Engagement: Authorial Identity in Professional and Apprentice Academic Genres. In C. S. Guinda (Ed.), Engagement in Professional Genres (pp. 29-46). John Benjamins.

https://doi.org/10.1075/pbns.301.02jia

Johns, A. M., \& Swalse, J. M. (2002). Literacy and Disciplinary Practices: Opening and Closing Perspectives. Journal of English for Academic Purposes, 1, 13-28. 
https://doi.org/10.1016/S1475-1585(02)00003-6

Jordan, R. R. (1998). English for Academic Purposes: A Guide and Resource Book for Teachers. Cambridge: Cambridge University Press. https://doi.org/10.1017/CBO9780511733062

Kim, S. (2006). Academic Oral Communication Needs of East Asian International Graduate Students in Non-Science and Non-Engineering Fields. English for Specific Purposes, 4, 479-489. https://doi.org/10.1016/j.esp.2005.10.001

Kwan, B. (2006). The Schematic; Structure of Literature Reviews of Doctoral Theses of Applied Linguistic. English for Specific Purpose, 25, 30-55. https://doi.org/10.1016/j.esp.2005.06.001

Lancaster, Z. (2016). Expressing Stance in Undergraduate Writing: Discipline-Specific and General Qualities. Journal of English for Academic Purposes, 23, 16-30. https://doi.org/10.1016/j.jeap.2016.05.006

Lei, J., \& Li, Y. Y. (2019). Teaching English for Research Publication Purposes: A Review of Pedagogical Practices. Journal of the Foreign Language World, 5, 48-56.

Li, Y. Y. et al. (2019). A Scientist in Interdisciplinary Team-Teaching in an English for Research Publication Purposes Classroom: Beyond a "Cameo Role". Journal of English for Academic Purposes, 40, 129-140. https://doi.org/10.1016/j.jeap.2019.06.005

Liu, Q., \& Liu, H. Y. (2020). A Survey on Academic English Teaching for Chinese Science and Engineering Majors in China. Journal of the Foreign Language World, 5, 47-54.

Luo, C. L. (2001). Postgraduate English Curriculum and the Cultivation of Language Proficiency-A Review of Prof. G.S. Hu's English for International Conference. Tsinghua Journal of Education, 3, 151-155.

Lv, C. H. et al. (2016). A Survey and Field Study on the Academic Writing Curriculum of American Universities. Journal of the Foreign Language World, 4, 43-49, 57.

Ma, X. L. el al. (2013). Theoretical and Practical Exploration into a Hierarchical Model of Academic Foreign Language Competence. Journal of the Foreign Language World, 1, $2-10$.

Mackey, A., \& Gass, S. M. (2015). Second Language Research: Methodology and Design (2nd ed.). New York: Routledge. https://doi.org/10.4324/9781315750606

Mandell, D. et al. (2015). Writing for Publication: Assessment of a Course for Social Work Doctoral Students. Journal of Teaching in Social Work, 35, 197-212. https://doi.org/10.1080/08841233.2014.983662

Mansourzadeh, K., \& Ahmad, U. K. (2011). Citation Practices among Non-Native Expert and Novice Scientific Writers. Journal of English for Academic Purposes, 10, 152-161. https://doi.org/10.1016/j.jeap.2011.03.004

Read, B., Francis, B., \& Robson, J. (2001). 'Play Safe': Understanding Essay Writing and the Presentation of the Student 'Voice'. British Journal of Sociology of Education, 22, 387-399. https://doi.org/10.1080/01425690124289

Swales, J. M. (1990). Genre Analysis: English in Academic and Research Settings. Cambridge: Cambridge University Press.

The National Advisory Committee on Teaching College English in Higher Education under the Ministry of Education (2020). The College English Teaching Guidelines (1st ed.). Beijing: Higher Education Press.

Wang, M., \& Liu, D. (2013). A Corpus-Based Study of the Use of Stance Expressions in English Research Article Manuscripts by Chinese EFL Learners. Modern Foreign Languages, 2, 190-197.

Wei, N. X. (2016). Rethingking of English for Academic Purposes: Its Theoretical Origins, 
Analytical Approaches and Pedagogical Methods. Modern Foreign Languages, 2, 267-277.

$\mathrm{Xu}, \mathrm{F}$. (2015). Study on Authorial Stance Markers in L2 Academic Writing. Foreign Language Teaching and Research, 1, 1-7.

Yang, H. Z. (2018). English for Academic Purposes or General English. Journal of the Foreign Language World, 5, 27-33.

Yu, W. S. (2014). Engineering Doctoral Students' Major Problems in English Scientific Paper Writing. Journal of the Foreign Language World, 3, 55-62.

Zhang, Z. Y. (2010). Exploring the Model of Postgraduate Academic English Writing Skills Development. Overseas English, 11, 15-16.

Zou, B. (2015). Implications of EAP Teaching at Sino-Foreign Cooperative Universities for College English Teaching in China: From the Perspective of Xi'an Jiaotong-Liverpool University. Journal of the Foreign Language World, 6, 69-76. 